\title{
À propos krajowej etnobotaniki
}

Nie tylko opis zjawiska, lecz także próba jego wyjaśnienia - oto „obowiązek” etnologa/ antropologa kultury, niezależnie od podejmowanego tematu. Dotyczy to również etnobotaniki, która jako „dyscyplina etnologii [...] zajmuje się badaniem wiedzy ludowej poszczególnych społeczności o świecie roślinnym oraz relacjami między tym światem a człowiekiem” (Kabat 1987: 84).

Da się natomiast powszechnie zauważyć, że wiele prac z tego zakresu, chyba najczęściej spotykanych w układzie roślina - lecznictwo, kończy się wyłącznie na opisie (gatunek rośliny, jaka jej część i w jakiej chorobie jest stosowana), pretendując tym samym do rozpraw etnobotanicznych, jeżeli już, to z pewnością mocno niepełnych. Kim są autorzy tych licznych opracowań, bo chyba nie etnologami ${ }^{1}$; często to botanicy, a także amatorzy różnych profesji, którzy nie są profesjonalnie związani ani z przyrodą, ani z kulturą w rozumieniu antropologicznym, po prostu „kochają kwiaty” - tak z tego wnioskuję. Trudno jednak przejść obok tego, nie reagując. Swego czasu (list datowany na 9 X 1887) Eliza Orzeszkowa „pochwaliła się" swemu przyjacielowi Janowi Karłowiczowi, redaktorowi „Wisły”: „w przerwach pomiędzy pisaniem i po jego ukończeniu zajmowałam się bardzo żywo i gorliwie światem roślin, botanizowałam ze szczególnym celem poznawania stosunku ludu naszego do otaczającej go natury (Orzeszkowa 1956: 78).

Określenie to, „botanizować, zapożyczyłem sobie od naszej pisarki, bowiem bardzo pasuje ono do praktyki tych piszących, o których wcześniej nadmieniłem; oni właśnie tylko botanizują, czyli bardzo płytko angażują się w problematykę, opisując li tylko fakty zarejestrowane „przez oko i ucho”. A przecież taka postawa badacza niewiele tu wyjaśnia.

Przepraszam za taki dydaktyzm, sam go nie cierpię i nigdy nie przypuszczałem, że kiedykolwiek nim się wspomogę, ale stało się, więc pociągnę to już do

\footnotetext{
1 Chociaż zdarzają się, patrz np. Kujawska 2013.
} 
końca w tej manierze, starając się jednak stępiać nieco moje ostrza pouczające, chociaż (!) można je potraktować także jako intencję li tylko wyjaśniającą.

Etnobotanika jest nauką humanistyczną, a nie nauką o kwiatkach (roślinach), zajmuje się: wiedzą, jaką człowiek posiada odnośnie do świata roślin, następnie wnika, na czym się ona zasadza, z czego wynika i w jakich sytuacjach, w jaki sposób z niej korzysta. A więc antropolog zajmujący się etnobotaniką nie kończy swojej pracy na etapie opisu zjawiska, ale od niego, tak na dobrą sprawę, zaczyna dopiero swoją działalność, nazwijmy ją "gabinetową"2. Stara się wyjaśnić, dlaczego ta roślina, ta jej część, w takich przypadkach, okolicznościach jest stosowana, z czego to wynika, jakie są przyczyny takiego postępowania, co się za nimi kryje. $\mathrm{W}$ tym celu stosuje odpowiednie metody i narzędzia, które poznał na studiach antropologicznych. Rozpatruje zagadnienie w szerszym kontekście kulturowym, który ma ułatwić mu pracę. W związku z tym należy zanurzyć się w poszukiwaniu sensu i znaczeń takich czy też innych praktyk. Należy pamiętać, że wiedza, wierzenia, przekonania, praktyki, czyli to wszystko, co odnosi się do etnobotaniki, nie jest czymś odosobnionym od innych „składowych” kultury. Są one ze sobą splecione, bo usankcjonowane jednym wspólnym światopoglądem.

Swego czasu pisałem:

Współczesna nauka jest dzisiaj mocno zróżnicowana i wyspecjalizowana, jest wiele nauk szczegółowych i ciągle wyłaniają się nowe. Odchodzą od siebie ze swoimi przedmiotami badawczymi, metodami - oddalają się. Ale zauważa się tendencje powrotów, wzajemnego poszukiwania się, uzupełniania - spojrzenia bardziej kompletnego, scalającego (Paluch 2012: 92).

Być może etnobotanice potrzebna jest współpraca instytucjonalnie zorganizowana. Etnolog parający się tymi zagadnieniami nie wszystko ogarnia, nie jest omnibusem, zasięga często porad u botanika w celu określenia gatunku konkretnej rośliny czy w innych podobnych przypadkach. Dla uchwycenia w pełni tej złożonej problematyki powinno się współpracować z farmakognostami, dendrologami, językoznawcami, socjologami, paleobotanikami; z każdym kto ma w tej kwestii coś sensownego do powiedzenia.

\section{Bibliografia}

Kabat I.

1987 Etnobotanika, w: Stownik etnologiczny, red. Z. Staszczak, Warszawa-Poznań. Kujawska M.

2013 Leczenie chorób ludowych za pomoca roślin przez Polonię argentyńską z Misiones, „Etnobiologia Polska”, vol. 1, s. 42.

2 Oto jeden z przykładów takiego postępowania w pracy (Libera, Paluch 1991: 141-153). 
Libera Z., Paluch A.

1991 Perypetie $z$ barwinkiem, czyli refleksje nad metoda $w$ etnobotanice, w: Metodologiczne problemy wspótczesnych badań nad kulturą i tradycją. Rozprawy, red. T. Karwicka, Toruń, s. 141-153.

Orzeszkowa E.

1956 Listy zebrane, t. 3, red. J. Baculewski, Wrocław.

Paluch A.

2012 W drodze do prawdy - jakiej?, Wrocław. 